\title{
The Attitude towards Smartphones and its Influence on Process, Social and Compulsive Usage
}

\author{
By J Dinesh Kumar* \\ $S$ Arulchelvan ${ }^{\prime}$
}

\begin{abstract}
The smartphone plays a major role in providing and integrating more features into a single device for the purpose of communication, entertainment, information seeking, e-services, healthcare, and agriculture. As such, it is important to study the influence of smartphones on various contexts. Hence this research looked at the influence of attitude on usage types among smartphone users in Chennai city, Tamil Nadu during October 2017. The study adopted the survey method to get responses from smartphone users. The result of the study indicates that the respondents of the study have a more positive attitude towards smartphones. The smartphone is mostly accessed for social use among the participants. With respect to age group, anxiety and compulsive use are significant and other variables are found to be non-significant. Males have a significant role in a negative attitude towards compulsive and social usage, and females have an important role in a positive attitude towards process and social usage and anxiety towards process usage.
\end{abstract}

Keywords: process usage, smartphone, social usage, technology attitude, technology influence.

\section{Introduction}

The smartphone is one of the major ICT developments that engage people in a new and different way. It is widely accessed for the purposes of entertainment, information sharing, education, healthcare services, e-governance, and ecommerce, etc. The effectiveness of smartphones has encouraged people to use them without a difference among age groups. Nowadays, communication and social networking mainly occur by accessing smartphones services. Young adults mostly use smartphones for entertainment, information sharing and seeking, while children use them for education and gaming, and older adults use them to spend leisure time (Muhanna \& Abu-Sha'r, 2009; Krithika \& Vasantha, 2013; Kang \& Jung, 2014; van Deursen, Bolle, Hegner, \& Kommers, 2015).

India is the third strongest and fast-growing country in the smartphone market. It grew 15\% during the first quarter of 2017 (Counterpoint Research, 2017). In India, among the 730.7 million mobile phone users in 2017, 340.2 million were smartphone users and this count is expected to rise to 467 million in 2021 (Statista, 2017). Among smartphone users, the majority of them also access internet services. According to the Internet and Mobile Association of India (IMAI, 2017), the Indian internet users' market is divided into two major categories, urban and rural. Among the urban population (444 million) and rural population (906 million), $60 \%$ and $17 \%$ of the populations respectively are internet users. This data shows that smartphone users are also internet users to

${ }^{*}$ Teaching Fellow \& Research Scholar, Department of Media Sciences, Anna University, India.

${ }^{\dagger}$ Assistant Professor, Department of Media Sciences, Anna University, India. 
some extent. The low-cost availability is also one of the reasons for the increase in smartphone usage. This combination of smartphone and internet facility provides various features in mobile phones to keep the people engaged with society, such as sending text messages through a messenger application, making online calls, listening to songs, watching online videos, getting directions through GPS, video chats, social networking applications, and using e-services, etc.

The enormous reach of smartphones among all age groups has an influence on the attitudes and usage patterns of people (van Deursen et al., 2015; Lane \& Manner, 2008). When analyzing the usage pattern among people, most of the studies said that young adults access smartphones more to gratify their needs and connect with society. People below 24 years of are identified as frequent smartphone users in India (Krithika \& Vasantha, 2013). When it comes to gender, men are identified as high users and technology addicts, whereas women are identified as moderate users. There have been many researchers who studied smartphone usage among people (Lane \& Manner, 2008; Krithika \& Vasantha, 2013; Rosen, Carrier, \& Cheever, 2013; Kang \& Jung, 2014; van Deursen et al., 2015; Ihm \& Hsieh, 2015; Lee, Chang, Lin, \& Cheng, 2014). But most of them are focused on youngsters (college-going adults). Despite the reach of smartphones among all age groups, previous studies concentrated more on young adults. Extensive age groups such as young to older adults are not considered in past studies. Furthermore, the study on attitudes toward smartphones and their influence on different types of user behavior are also less concentrated among smartphone user groups.

Therefore, the need arises to figure out how attitude and usage type are related and influence smartphone users. To address this gap, this research has attempted to identify the influence of attitude on usage types. Hence, this particular study presented three objectives. They are (1) to understand the attitude towards smartphones among people, (2) to identify the usage pattern for smartphones among people, and (3) to find out the influence of attitude on usage among people. Age group and gender difference were also studied.

\section{Theoretical Background}

This particular section provides insights into attitude towards and usage of smartphones as found in existing literature. The attitude and usage of the different gender and age groups are also presented.

\section{Smartphone Usage}

The multi-feature aspects in smartphones made all the age groups of people able to access them without any divide. But significant difference in usage with respect to age group and gender is identified in many studies (Kang \& Jung, 2014; Lane \& Manner, 2008; van Deursen et al., 2015).

Smartphones have become pervasive devices, used not only for voice calls and messaging services, but also for games, media consumption, various services 
from all sectors, navigational assistance, and so on (Dvinsky \& Friedman, 2015). The social usage of smartphones is related to the development of relationships, social interaction, and internet behavior, etc. (Chou \& Hsiao, 2000; Yang \& Tung, 2007). Smartphones help people to develop and retain social connections through effective communication platforms, such as chat applications, social networking services available in it. Song, Larose, Eastin, and Lin, (2004) have proposed the notion of process related gratification. It is acquired while consuming media. Smartphone usage helps to manage the day-to-day activities of people, such as paying bills, reading news, connecting with family, friends and peers, listening to songs, watching movies, searching for instant information, and reading emails, etc. Compulsive behavior or usage occurs when these activities shift to repetitive checking of the device (Oulasvirta, Rattenbury, Ma, \& Raita, 2012). Tedious usage of smartphones without any control, early distraction by phones, spending more time with the phone, unsuccessful efforts to control usage, and feelings of restlessness are a few things considered as symptoms of compulsive usage of smartphones. In certain cases, other than social and process usage, compulsive usage causes harm to the individual or to others and induces stress (O'Guinn \& Faber, 1989).

With reference to demographic elements, younger adults, such as the 21-30 age groups, are more often using the smartphone with the internet. They use it mostly to socialize and coordinate their life, whereas older adults spend less time on a smartphone resulting in less social stress and better self-regulation (van Deursen et al., 2015). Older adults are less likely to hold the new technological innovations compared to younger adults (Charness \& Bosman, 1992). The younger age group is considered to be regulated less, habitual and more addictive than the older age group (van Deursen et al., 2015).

Many studies also show a gender difference in technology and smartphone access (Krithika \& Vasantha, 2013; Matthews, Roberts, \& Zeidner, 2004; Lee et al., 2014; van Deursen et al., 2015). When analyzing by gender, males spend more time using mobile phones than females (Devis, Carmen, Vicente, \& Thomas, 2009). Males show more skills and interests towards technology, and females are more into satisfying their social motives. Males use the smartphones for agentic purposes and females use it for communal purposes (Lenhart, Purcell, Smith, \& Zickuhr, 2010). Males are more likely to embrace technology and thus become more problematic in their usage than females. When females recognize their own problematic technology use, they cut back or stop their use (Rotsztein, 2003). Based on these literature insights related to technology and smartphone usage, three main types of usage - social, process and compulsive - are proposed.

\section{Attitude towards Smartphones}

Attitude refers to the feelings, beliefs, and tendencies towards any object or concept (Khatun, Rana, \& Ali, 2017). It is the knowledge we possess that can be positive or negative (Priester \& Petty, 1996). Smartphones are the first thing people look at in the morning and the last thing at night (Oulasvirta et al., 2012). According to Pew Research Centre (2014), smartphone users use their 
devices to meet a wide range of needs, such as banking, healthcare, education, jobrelated information, and real estate. Smartphones has also been seen as a motivational factor and assistance for learning and growing individual capabilities (Campbell, 2007), entertainment, relationship development, security and relaxation (Hostut, 2010) among all the age groups.

Among young adults, disagreeable individuals spend more time on calls and those who have low self-esteem prefer instant messaging (Ehrenberg, Juckes, White, \& Walsh, 2008). People with low agreeableness (differences in levels of cooperation and social harmony) prefer to play more games (Phillips, Butt, \& Blaszczynski, 2008). Muhanna et al. (2009) have found positive attitudes towards smartphone usage among students in a learning environment, though this trend has more influence on males than females. Navabi, Ghaffari, and Jannat-Alipoor (2016) found that older adults have a negative attitude towards smartphone use due to anxiety. The same study has observed that attitude scores are lower in females compared to males ( $71.66 \%$ female and $72.85 \%$ male). Lelkes (2013) found that older people failed to use the internet on smartphones, because of low literacy levels, delayed learning and forgetfulness. They fear that accessing unknown things on smartphones will cause problems, and thus it leads to technology fear. Smartphones have also made a certain group of people addicted to their phones. Oulasvirta et al. (2012) have found that people are checking their smartphones approximately 34 times per day, even if no updates are available. A study conducted by IDC (2013) found that eight in 10 adults check their smartphones within 15 minutes of waking. Kamibeppu and Sugiura (2005) found that most of the young smartphone users in their research felt insecure if their messages were unanswered. The literature studies discussed here provide insights into how attitudes towards smartphones may be positive, negative or anxious. Following this foundation, this research categorized attitudes into positive, negative and anxious, and measured the influence of those different attitudes towards smartphones as related to age and gender.

\section{Conceptual Model and Research Questions}

Based on the insights from the literature, the conceptual model and research questions were framed and presented (Figure 1).

The following research questions were developed based on the literature to study this research objective.

1. What is the influence of different types of attitudes on the usage of smartphones?

2. What is the influence of different types of attitudes and usage patterns among the various age groups of smartphone users?

3. What is the influence of different types of smartphone usage patterns among the gender groups of smartphone users? 
Figure 1. Conceptual Model-Influence of Attitude on Usage Types of Smartphones among Adults

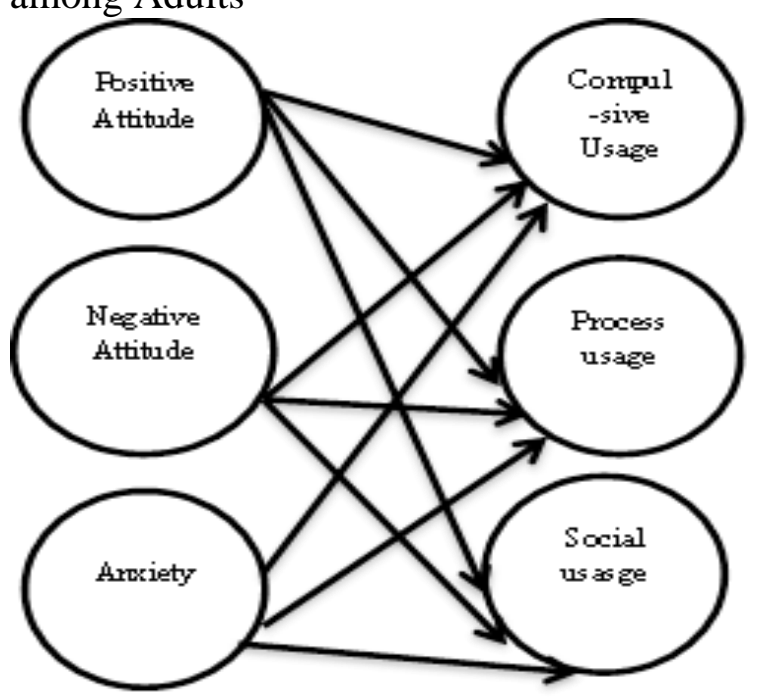

Based on the above research questions, the following hypotheses were framed.

1. There is an influence of various types of attitudes on the social, process and compulsive usage of smartphones.

2. Different age groups of people have different attitudes and usage patterns in regards to their smartphones.

3. Gender plays an influential role in smartphone usage.

\section{Methodology}

\section{Procedure and Sample Selection}

This present study was designed as a cross-sectional study, and the data were collected through survey questionnaires during October-November 2017 in Chennai City. Chennai City is one of the important cosmopolitan cities located in Tamil Nadu, India, and it recorded the highest mobile phone users (Census India, 2011) in Tamil Nadu state. A purposive sampling technique was adopted for this study, and smartphone users along with internet facilities were selected. We met each of the respondents in person and gave them the questionnaire to be filled. Out of 400 survey forms and online links circulated, 160 responses were recorded. Due to the lack of complete information, 15 questionnaires were considered invalid and removed during the data cleaning process. Finally, 145 respondents were taken into consideration. The approximate time needed to fill the survey was 20 minutes. Table 1 summarizes the demographic profile. The mean age of the respondents is 36.9 years $(\mathrm{SD}=10.3)$, with participants ranging from 20 to 65 years. The female samples $(54.5 \%)$ outnumbered the male. 
Vol. 4, No. $4 \quad$ Kumar et al: The Attitude towards Smartphones and its Influence on...

Table 1. Demographic Profile of the Respondents $(\mathrm{N}=145)$

\begin{tabular}{|l|l|c|c|}
\hline \multirow{3}{*}{ Gender } & Male & $\mathbf{N}$ & \% \\
\cline { 2 - 4 } & Female & 66 & 45.5 \\
\hline \multirow{3}{*}{ Age group } & Young adults (20-35 years) & 79 & 54.5 \\
\cline { 2 - 4 } & Middle-aged adults (36-50 years) & 86 & 59.4 \\
\cline { 2 - 4 } & Older adults (50-65 years) & 44 & 30.3 \\
\hline
\end{tabular}

\section{Measures}

To test the attitude towards smartphone usage, we have adopted a part of Media and Technology Usage and Attitudes scales (MTUAS) (Rosen et al., 2013); the constructs from this established measure were modified a little to fit into this research study. Where technology and mobile phones were mentioned in few places, we replaced them with the word smartphones to make it more meaningful to the study. Twelve constructs were selected from the measurement scale titled under positive attitude, negative attitude and anxiety/dependence. These were measured using a five point Likert scale for all items from "strongly agree" to "strongly disagree". To measure user behavior, the scales were adapted from different studies for each variable. The compulsive usage scale was derived from Lee et al. (2014), which was originally derived from other various works (Meerkerk, Van der Eijnden, Vermulst, \& Garretsen, 2009; Ehrenberg et al., 2008; Jenaro, Flores, Gomez-Vela, Gonzalez-Gill, \& Caballo, 2007), and consisted of thirteen items. The 7 point Likert scale was modified to be a 5 point Likert scale. The 7 item process usage scale and 5 item social usage scale were derived from van Deursen et al. (2015), which was was originally adapted from Chua, Goh, and Lee (2012). The various ranges of scales (5 points and 7 points) from the different studies were taken and modified to be 5 point scales in order to uniformly to get the responses.

\section{Analytical Procedure}

We used a Partial Least Squares (PLS) test to validate our model. To test our research questions and the relations between paths, the two-step approach was employed. We first checked the different criteria of the measurement model, and then assessed the structural model. To examine the age group differences with different types of attitudes and usage of smartphones, a new factor called "age" was included in the SEM model and the estimation was recorded. Further, the influence of positive attitude, negative attitude, and anxiety on compulsive, process and social usage with a difference of gender is explored through multigroup analysis. 


\section{Results}

\section{Preliminary Analysis}

The preliminary analysis results summarise the respondents' opinions about the different types of attitude and usage. Positive attitude (3.42) is the highest among the types of attitude when comparing it to negative attitude (2.44) and anxiety (1.94) among the respondents. With respect to usage, respondents use the smartphone for satisfying their social needs, i.e. social usage (3.76), more than process (3.47) and compulsive usage (1.48). This indicates that the respondents of the study have a more positive attitude towards their smartphones. Social usage is the most preferred usage type, followed by process usage. This indicates that respondents use smartphones more to satisfy their social, as well as processual, needs. The compulsive usage and anxiety had the lowest mean values compared to the other associated types.

\section{Measurement Model}

In the measurement model, during scale purification, only values greater than 0.50 loading values were considered (Nunnally, 1978; Hair, Black, Babin, Anderson, \& Tatham, 2010); other items were eliminated from the original survey questionnaire. One item from anxiety and six items from compulsive usage was deleted. After removing those 7 items, the remaining items were loaded again and significant results were derived. Table 2 shows the PLS loadings of all the items.

Table 3 displays the results of reliability and validity. Construct reliability in this model was identified through composite reliabilities, Cronbach's alpha and average variance extracted (AVE). The composite reliability of all the constructs was in the accepted range above 0.80 (i.e. 0.882 to 0.920) (Peter, 1979). The reliability of the measurement model was supported by testing the Cronbach's alpha, which was found to be above 0.70 (i.e. 0.750 to 0.891) (Nunnally, 1978; Hair et. al., 2010) for all the statements. This proved the stronger reliability of the constructs in the measurement model. The average variance extracted by all the constructs was above 0.50 (i.e. 0.523 to 0.851 ). Hence, the convergent validity of the constructs was found to be strong in this model.

Table 2. PLS Loadings of Different Types of Attitude and Usage of Smartphone

\begin{tabular}{|c|c|c|c|c|c|c|c|}
\hline No. & Statements & \begin{tabular}{|l|} 
Positive \\
Attitude \\
\end{tabular} & \begin{tabular}{|l} 
Negative \\
Attitude \\
\end{tabular} & Anxiety & \begin{tabular}{|c|}
$\begin{array}{c}\text { Compulsive } \\
\text { Usage }\end{array}$ \\
\end{tabular} & \begin{tabular}{|c|} 
Process \\
Usage \\
\end{tabular} & \begin{tabular}{|l} 
Social \\
Usage \\
\end{tabular} \\
\hline 1. & $\begin{array}{l}\text { I feel smartphone is important to be } \\
\text { able to find any information } \\
\text { whenever I want online. }\end{array}$ & 0.732 & & & & & \\
\hline 2. & $\begin{array}{l}\text { I feel smartphone is important to be } \\
\text { able to access the Internet any time } \\
\text { I want. }\end{array}$ & 0.724 & & & & & \\
\hline 3. & $\begin{array}{l}\text { I think it is important to keep up } \\
\text { with the latest trends in technology } \\
\text { in smartphones. }\end{array}$ & 0.820 & & & & & \\
\hline 4. & $\begin{array}{l}\text { Smartphones will provide solutions } \\
\text { to many of our problems. }\end{array}$ & 0.713 & & & & & \\
\hline 5. & $\begin{array}{l}\text { With smartphones anything is } \\
\text { possible. }\end{array}$ & 0.739 & & & & & \\
\hline
\end{tabular}


Vol. 4, No. $4 \quad$ Kumar et al: The Attitude towards Smartphones and its Influence on...

\begin{tabular}{|c|c|c|c|c|c|c|c|}
\hline No. & Statements & \begin{tabular}{|l|} 
Positive \\
Attitude \\
\end{tabular} & $\begin{array}{l}\text { Negative } \\
\text { Attitude }\end{array}$ & Anxiety & $\begin{array}{c}\text { Compulsive } \\
\text { Usage }\end{array}$ & \begin{tabular}{|c|} 
Process \\
Usage \\
\end{tabular} & $\begin{array}{l}\text { Social } \\
\text { Usage }\end{array}$ \\
\hline 6. & $\begin{array}{l}\text { I feel that I get more accomplished } \\
\text { because of smartphones. }\end{array}$ & 0.736 & & & & & \\
\hline 7. & $\begin{array}{l}\text { Smartphones make people waste } \\
\text { too much time. }\end{array}$ & & 0.785 & & & & \\
\hline 8. & $\begin{array}{l}\text { Smartphones make life more } \\
\text { complicated. }\end{array}$ & & 0.729 & & & & \\
\hline 9. & $\begin{array}{l}\text { Smartphones make people more } \\
\text { isolated. }\end{array}$ & & 0.909 & & & & \\
\hline 10. & $\begin{array}{l}\text { I get anxious when I don't have my } \\
\text { cell phone. }\end{array}$ & & & 0.931 & & & \\
\hline 11. & $\begin{array}{l}\text { I get anxious when I don't have the } \\
\text { Internet available on my mobile } \\
\text { phone. }\end{array}$ & & & 0.915 & & & \\
\hline 12. & $\begin{array}{l}\text { The first thing I do each morning is } \\
\text { to check my mobile phone for } \\
\text { missed calls or messages. }\end{array}$ & & & & 0.675 & & \\
\hline 13. & $\begin{array}{l}\text { I risk an important relationship, a } \\
\text { job, an academic opportunity or a } \\
\text { career development opportunity } \\
\text { because I overuse my mobile } \\
\text { phone. }\end{array}$ & & & & 0.651 & & \\
\hline 14. & $\begin{array}{l}\text { I try to not use my mobile phone } \\
\text { frequently but I am unsuccessful. }\end{array}$ & & & & 0.727 & & \\
\hline 15. & $\begin{array}{l}\text { I often anticipate my next use of } \\
\text { my mobile phone. }\end{array}$ & & & & 0.748 & & \\
\hline 16. & $\begin{array}{l}\text { I check for missed calls and } \\
\text { messages all the time when I am } \\
\text { awake. }\end{array}$ & & & & 0.744 & & \\
\hline 17. & $\begin{array}{l}\text { I use my mobile phone even when } \\
\text { talking or eating with others. }\end{array}$ & & & & 0.714 & & \\
\hline 18. & $\begin{array}{l}\text { I prefer to use my mobile phone } \\
\text { rather than spend time with others. }\end{array}$ & & & & 0.795 & & \\
\hline 19. & $\begin{array}{l}\text { I use my smartphone in order to } \\
\text { escape from real-life. }\end{array}$ & & & & & 0.550 & \\
\hline 20. & $\begin{array}{l}\text { I use my smartphone in order to } \\
\text { relax. }\end{array}$ & & & & & 0.784 & \\
\hline 21. & $\begin{array}{l}\text { I use my smartphone because it is } \\
\text { entertaining. }\end{array}$ & & & & & 0.869 & \\
\hline 22. & $\begin{array}{l}\text { I use my smartphone because it } \\
\text { informs me of things that happen in } \\
\text { everyday life. }\end{array}$ & & & & & 0.825 & \\
\hline 23. & $\begin{array}{l}\text { I use my smartphone in order to } \\
\text { stay up to date of the latest news. }\end{array}$ & & & & & 0.703 & \\
\hline 24. & $\begin{array}{l}\text { I use my smartphone because it } \\
\text { helps me passing time. }\end{array}$ & & & & & 0.784 & \\
\hline 25. & $\begin{array}{l}\text { I use my smartphone because it's a } \\
\text { pleasant break from my routines. }\end{array}$ & & & & & 0.808 & \\
\hline 26. & $\begin{array}{l}\text { I use my smartphone to interact } \\
\text { with people. }\end{array}$ & & & & & & 0.872 \\
\hline 27. & $\begin{array}{l}\text { I use my smartphone to maintain } \\
\text { relationships. }\end{array}$ & & & & & & 0.836 \\
\hline 28. & $\begin{array}{l}\text { I use my smartphone to call other } \\
\text { people. }\end{array}$ & & & & & & 0.818 \\
\hline 29. & $\begin{array}{l}\text { I use my smartphone to text } \\
\text { message others. }\end{array}$ & & & & & & 0.817 \\
\hline 30. & $\begin{array}{l}\text { I use my smartphone to contact } \\
\text { people through social media. }\end{array}$ & & & & & & 0.828 \\
\hline
\end{tabular}


Table 3. Reliability, Correlations and AVEs of Attitude and Usage Factors

\begin{tabular}{|l|c|c|c|c|c|c|c|c|c|}
\hline & $\begin{array}{c}\text { Composite } \\
\text { Reliability }\end{array}$ & $\begin{array}{c}\text { Cronbach's } \\
\text { alpha }\end{array}$ & $\mathbf{A V E}$ & $\begin{array}{c}\text { Positive } \\
\text { Attitude }\end{array}$ & $\begin{array}{c}\text { Negative } \\
\text { Attitude }\end{array}$ & $\begin{array}{c}\text { Anxiety } \\
\text { Compulsive } \\
\text { Usage }\end{array}$ & $\begin{array}{c}\text { Process } \\
\text { Usage }\end{array}$ & $\begin{array}{l}\text { Social } \\
\text { Usage }\end{array}$ \\
\hline $\begin{array}{l}\text { Positive } \\
\text { Attitude }\end{array}$ & 0.882 & 0.840 & 0.555 & $\mathbf{0 . 7 4 5}$ & & & & & \\
\hline $\begin{array}{l}\text { Negative } \\
\text { Attitude }\end{array}$ & 0.851 & 0.750 & 0.657 & 0.090 & $\mathbf{0 . 8 1 1}$ & & & & \\
\hline Anxiety & 0.920 & 0.826 & 0.851 & -0.367 & 0.040 & $\mathbf{0 . 9 2 3}$ & & & \\
\hline $\begin{array}{l}\text { Compulsive } \\
\text { Usage }\end{array}$ & 0.884 & 0.848 & 0.523 & 0.370 & 0.177 & -0.603 & $\mathbf{0 . 7 2 3}$ & & \\
\hline $\begin{array}{l}\text { Process } \\
\text { Usage }\end{array}$ & 0.908 & 0.879 & 0.588 & 0.407 & -0.096 & -0.565 & 0.457 & $\mathbf{0 . 7 6 7}$ & \\
\hline $\begin{array}{l}\text { Social } \\
\text { Usage }\end{array}$ & 0.920 & 0.891 & 0.697 & 0.493 & -0.268 & -0.308 & 0.298 & 0.610 & $\mathbf{0 . 8 3 5}$ \\
\hline
\end{tabular}

In order to examine the discriminant validity, Fornell and Larcker's (1981) procedure was adopted here. Discriminant validity is assessed by comparing the square root of average variance extracted (AVE) with correlation of the latent constructs. The square roots of the AVEs should be greater than the correlation between the different constructs. When analyzing Table 3, it is clear that the values of the square roots of AVE are higher than the other constructs. Hence, the discriminant validity is proved. The requirement of the measurement model is validated with the required values in this model. Thus, the measurement model is also proved.

\section{Structural Model}

All basic assumptions for the structural model were met. The standardized path coefficients between the different types of attitudes and usage reveal the answers to the research problems. Figure 2 shows the model analysis of these results. The results ( $\mathrm{R}$ Square value) show that different types of attitudes (independent variables) together are significant predictors of compulsive usage, process usage and social usage with $42 \%, 38 \%$ and $35 \%$, respectively, of the variance in the dependent variable accounted for.

Table 4 denotes the standardized path estimates between factors. With reference to such data, the structural model denotes that positive attitude influences compulsive (0.149), process $(0.243)$ and social usage (0.476) positively. Among the three different types of usage, positive attitude influences social usage more than the two other types of smartphone usage. When analyzed for negative attitude, positive influence is seen only with regards to compulsive usage (0.186). It negatively influences the social (-0.306) and process usage (-0.099). Anxiety was shown to negatively influence all three types of usage: compulsive $(-0.556)$, process (-0.472) and social (-0.121) usage.

To determine the significant relationship between the structural paths, the model generated the T-statistics value through a bootstrapping method using a two-tailed t-test with a significant level of 5\%. The statistic T-value, which is more than 1.96, is considered to be significant (David Garson, 2016). The bootstrap result approximates the normality of the data. Table 4 also displays the T-statistics of the path coefficients between factors (i.e. for the inner model). The values denote that, except for the paths between positive attitude and compulsive usage 
Vol. 4, No. $4 \quad$ Kumar et al: The Attitude towards Smartphones and its Influence on...

(1.845), negative attitude and process usage (1.188), and anxiety and social usage (1.626), all other path values are higher than 1.96 and thus found to be significant.

Table 4. Standardized Path Estimates Between the Factors

\begin{tabular}{|l|c|c|c|}
\hline Path & $\begin{array}{c}\text { Standardized } \\
\text { Estimates }\end{array}$ & T-statistics & Result \\
\hline Positive Attitude $\longrightarrow$ Compulsive usage & 0.149 & 1.845 & $\mathrm{NS}$ \\
\hline Positive Attitude $\longrightarrow$ Process usage & 0.243 & 2.909 & $\mathrm{~S}$ \\
\hline Positive Attitude $\longrightarrow$ Social usage & 0.476 & 6.518 & $\mathrm{~S}$ \\
\hline Negative Attitude $\longrightarrow$ Compulsive usage & 0.186 & 2.328 & $\mathrm{~S}$ \\
\hline Negative Attitude $\longrightarrow$ Process usage & -0.099 & 1.188 & $\mathrm{NS}$ \\
\hline Negative Attitude $\longrightarrow$ Social usage & -0.306 & 4.944 & $\mathrm{~S}$ \\
\hline Anxiety $\longrightarrow$ Compulsive usage & -0.556 & 8.654 & $\mathrm{~S}$ \\
\hline Anxiety $\longrightarrow$ Process usage & -0.472 & 6.705 & $\mathrm{~S}$ \\
\hline Anxiety $\longrightarrow$ Social usage & -0.121 & 1.626 & $\mathrm{NS}$ \\
\hline
\end{tabular}

Note: S-Significant, NS-Not Significant.

Figure 2. PLS-SEM Model-Attitude and Usage of Smartphones among Adults

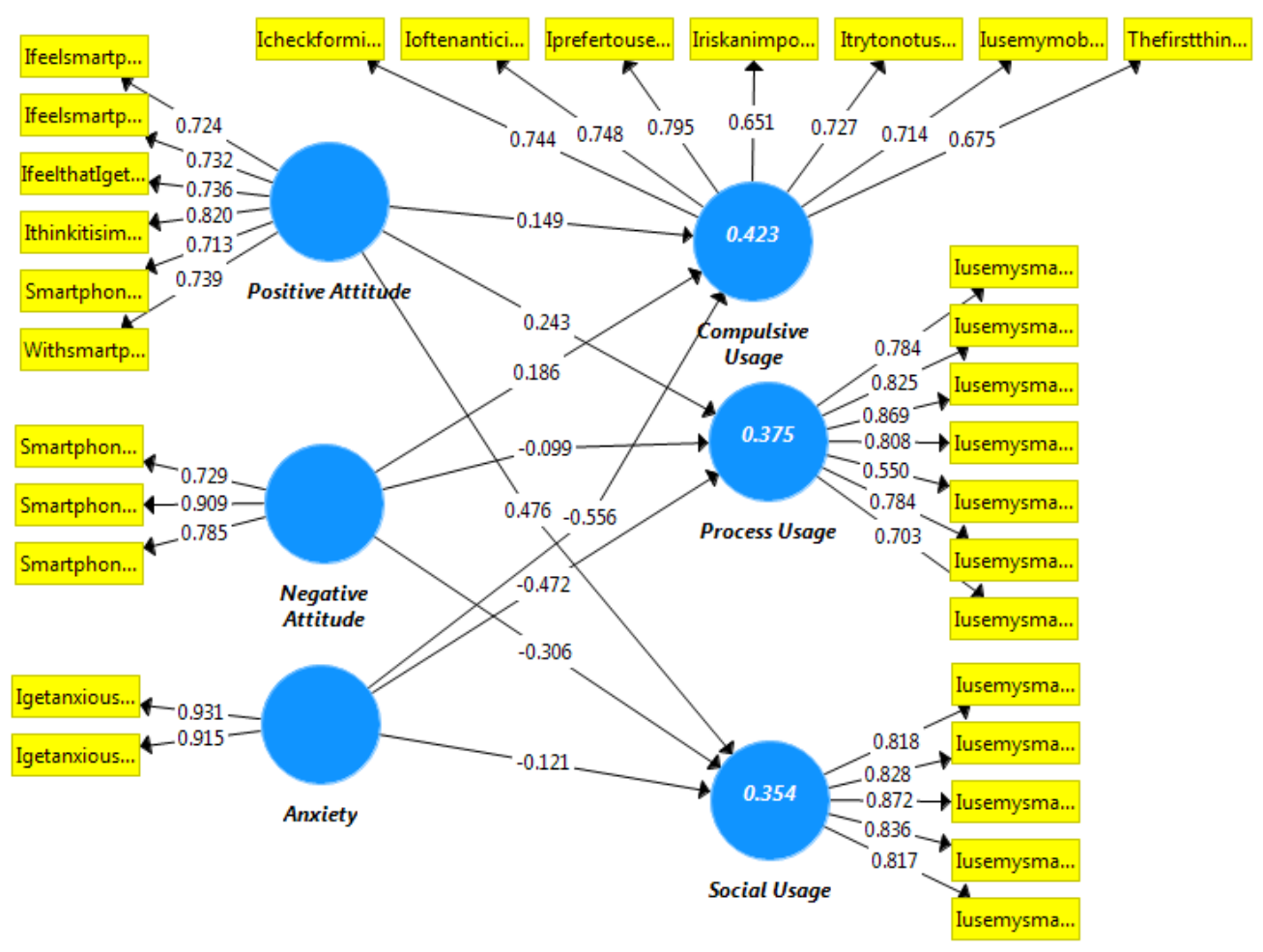

\section{Moderating Age and Gender Differences}

The output of the PLS model included age and gender as factors.

The result of age group analysis. Figure 3 displays the actual SEM model with age as a factor, measuring the influence of age group on all types of attitude and usage of smartphones. T-values which denote the significance of paths 
between factors were displayed in Figure 3. As per the model, age significantly influences anxious attitudes (3.093) and compulsive usage (3.144). Other factors, such as positive attitude (1.632), negative attitude (0.539), process usage $(0.280)$ and social usage $(0.871)$, though slightly influenced, did not attain a significant Tvalue greater than 1.96 . The paths highlighted from thin to thick lines denote the elevation of significant values from lower to higher. Hence, as per the figure, the path significance between the four paths does not have an influence with reference to age group.

Figure 3. PLS-SEM Model-Age Group Analysis

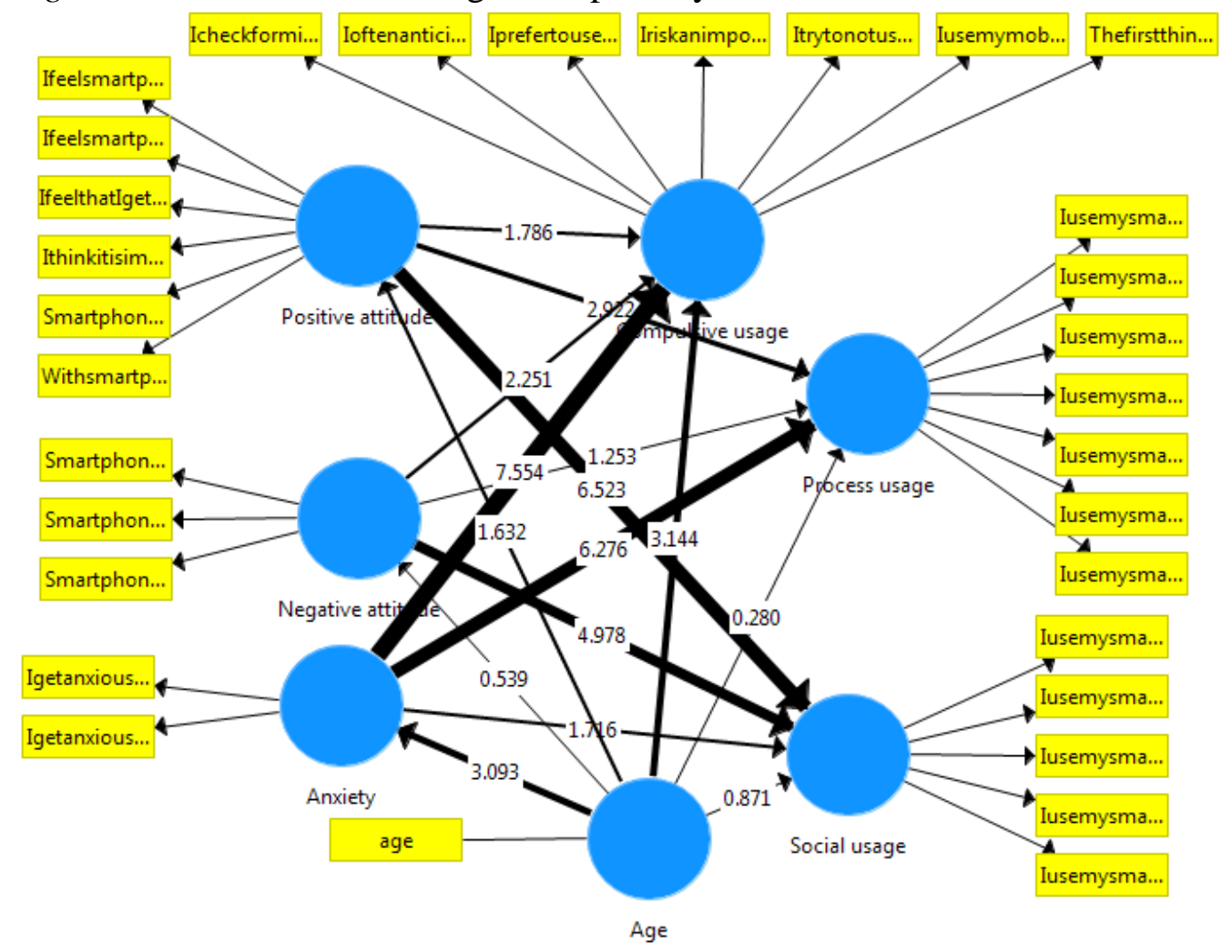

The result of gender analysis. The multi-group analysis result between male and female is presented below. In PLS, the measure of the difference between different groups was interpreted based on the comparison of path estimates between the groups (Lee et al., 2014; David Garson, 2016). In some cases, however, even small differences in coefficients show a significant value. Therefore, identification of the distance between the coefficients is recommended (David Garson, 2016). That difference was also subjected to three tests, including PLS Multi-Group Analysis (PLS-MGA), parametric test and Welch Satterthwaite Test. In PLS-MGA non-parametric test, if the p-value is smaller than 0.05 or larger than 0.95 , the path is said to be significant. The parametric test is also a similar method, but it assumes that the groups have equal variance, whereas the WelchSatterthwaite test assumes unequal variance between groups (David Garson, 2016). Thus, this research identified the difference between gender in all four recommended ways. 
Table 5 shows the analysis of path estimates of gender differences in the relationship between the different types of attitudes and usage of smartphones. The results were derived based on the path estimates of the multi-group analysis, and the significant relationships were analyzed by looking at the $\mathrm{T}$ and $\mathrm{P}$ values. Among the possible paths, positive attitude to compulsive usage, negative attitude to process usage, and anxiety to social usage were found to be non-significant. This was similar to the overall model. Other paths were found to be significant, however. Among those, a positive attitude towards process and social usage and anxiety towards process usage were stronger for female than for male respondents. On the other hand, negative attitudes towards compulsive and social usage and anxiety to compulsive usage were stronger for male participants than female participants. Apart from this, the model also checked for the confidence interval, which is essential to estimate the existence of path coefficient difference between male and female samples in the model. Multi-group analysis with this model noted an overlapping confidence interval (estimation values between male and female are higher to lower and lower to higher between paths). Hence at the 0.05 significance level, we identified no difference in the path coefficients between male and female respondents.

Table 5. Path Estimates of Gender Differences in Relationships between the Influence of Different Types of Attitude and Usage of the Smartphone

\begin{tabular}{|c|c|c|c|c|c|}
\hline \multirow[t]{2}{*}{ Path } & \multicolumn{2}{|c|}{ Standardized estimates } & \multicolumn{2}{|c|}{ T-values } & \multirow[t]{2}{*}{ Results } \\
\hline & $\begin{array}{c}\text { Males } \\
(\mathrm{N}=66)\end{array}$ & $\begin{array}{c}\text { Females } \\
(N=79)\end{array}$ & $\begin{array}{l}\text { Males } \\
(\mathrm{N}=66)\end{array}$ & $\begin{array}{c}\text { Females } \\
(\mathbf{N}=79)\end{array}$ & \\
\hline Positive Attitude $\longrightarrow$ Compulsive Usage & 0.179 & 0.111 & 1.576 & 0.900 & NS \\
\hline Positive Attitude $\longrightarrow$ Process Usage & 0.260 & 0.306 & $2.197 *$ & $2.370 *$ & $\mathrm{~F}>\mathrm{M}$ \\
\hline Positive Attitude $\longrightarrow$ Social Usage & 0.375 & 0.607 & $3.815 * * *$ & $5.759 * * *$ & $\mathrm{~F}>\mathrm{M}$ \\
\hline Negative Attitude $\longrightarrow$ Compulsive Usage & -0.003 & 0.315 & 0.029 & $3.089 * *$ & $\mathrm{M}>\mathrm{F}$ \\
\hline Negative Attitude $\longrightarrow$ Process Usage & -0.101 & -0.126 & 0.593 & 1.321 & NS \\
\hline Negative Attitude $\longrightarrow$ Social Usage & -0.426 & -0.260 & $2.946 * *$ & $4.098 * * *$ & $\mathrm{M}>\mathrm{F}$ \\
\hline Anxiety $\longrightarrow$ Compulsive Usage & -0.645 & -0519 & $7.853 * * *$ & $5.917 * * *$ & $\mathrm{M}>\mathrm{F}$ \\
\hline Anxiety $\longrightarrow$ Process Usage & -0.465 & -0.445 & $4.463 * * *$ & $4.553 * * *$ & $\mathrm{~F}>\mathrm{M}$ \\
\hline Anxiety $\longrightarrow$ Social Usage & -0.230 & -0.009 & 1.953 & 0.108 & NS \\
\hline
\end{tabular}

Note: $\mathrm{M}=$ Males, $\mathrm{F}=\mathrm{Females}, \mathrm{NS}=$ Not significant.

$* \mathrm{p}<0.05 ; * * \mathrm{p}<0.01 ; * * * \mathrm{p}<0.001$

Examining Table 6, except for negative attitude towards compulsive usage and anxiety towards social usage, all other differences are not significant in any of the tests. In this case, the model is said to be same for both groups (David Garson, 2016). Hence, we conclude that the same PLS path model applies to both male and female. 
Table 6. Comparison of Gender Differences in Relationships between the Different Types of Attitude and Usage of the Smartphone

\begin{tabular}{|l|c|c|c|c|c|c|c|c|}
\hline \multirow{2}{*}{ Path } & \multicolumn{2}{|c|}{ PLS-MGA } & \multicolumn{3}{|c|}{ Parametric test } & \multicolumn{3}{c|}{ Welch-Satterthwaite test } \\
\cline { 2 - 10 } & $\begin{array}{c}\text { Path } \\
\text { Coefficient } \\
\text { difference } \\
(M-F)\end{array}$ & $\begin{array}{c}\text {-values } \\
(M \text { vs } F)\end{array}$ & $\begin{array}{c}\text { Path } \\
\text { Coefficient } \\
\text { difference } \\
(M-F)\end{array}$ & $\begin{array}{c}\text { T-values } \\
(M \text { vs } F)\end{array}$ & $\begin{array}{c}\text { P-values } \\
(M \text { vs } F)\end{array}$ & $\begin{array}{c}\text { Path } \\
\text { Coefficient } \\
\text { difference } \\
(M-F)\end{array}$ & $\begin{array}{c}\text { T-values } \\
(M \text { vs } F)\end{array}$ & $\begin{array}{c}\text { P-values } \\
(M \text { vs } F)\end{array}$ \\
\hline $\begin{array}{l}\text { Positive Attitude } \rightarrow \\
\text { Compulsive Usage }\end{array}$ & 0.067 & 0.349 & 0.067 & 0.397 & 0.692 & 0.067 & 0.404 & 0.687 \\
\hline $\begin{array}{l}\text { Positive Attitude } \\
\text { Process Usage }\end{array}$ & 0.046 & 0.605 & 0.046 & 0.263 & 0.793 & 0.046 & 0.267 & 0.790 \\
\hline $\begin{array}{l}\text { Positive Attitude } \rightarrow \\
\text { Social Usage }\end{array}$ & 0.232 & 0.946 & 0.232 & 1.586 & 0.115 & 0.232 & 1.611 & 0.112 \\
\hline $\begin{array}{l}\text { Negative Attitude } \rightarrow \\
\text { Compulsive Usage }\end{array}$ & 0.315 & 0.977 & 0.315 & 2.156 & 0.033 & 0.315 & 2.165 & 0.034 \\
\hline $\begin{array}{l}\text { Negative Attitude } \rightarrow \\
\text { Process Usage }\end{array}$ & 0.025 & 0.475 & 0.025 & 0.135 & 0.893 & 0.025 & 0.129 & 0.898 \\
\hline $\begin{array}{l}\text { Negative Attitude } \rightarrow \\
\text { Social Usage }\end{array}$ & 0.166 & 0.890 & 0.166 & 1.143 & 0.255 & 0.166 & 1.084 & 0.283 \\
\hline $\begin{array}{l}\text { Anxiety } \rightarrow \\
\text { Compulsive Usage }\end{array}$ & 0.126 & 0.853 & 0.126 & 1.031 & 0.304 & 0.126 & 1.046 & 0.299 \\
\hline $\begin{array}{l}\text { Anxiety } \rightarrow \\
\text { Process Usage }\end{array}$ & 0.020 & 0.560 & 0.020 & 0.136 & 0.892 & 0.020 & 0.137 & 0.892 \\
\hline $\begin{array}{l}\text { Anxiety } \rightarrow \\
\text { Social Usage }\end{array}$ & 0.238 & 0.952 & 0.238 & 1.031 & 0.082 & 0.238 & 1.703 & 0.093 \\
\hline
\end{tabular}

Note: $\mathrm{P}$ values in italics indicate difference in significance.

\section{Discussion}

\section{Main Findings}

Analysis of the attitudes and usage patterns regarding smartphones among the respondents in this research achieved both significant and non-significant results in various cases. The influence of different types of attitude towards usage types (research question 1) was analyzed by running a PLS Model. The result shows that positive attitude has a positive path coefficient with all three usage types. A negative attitude is associated positively with compulsive usage, but is associated negatively with social and process usage. Anxiety negatively influences all types of usage.

Because the results show a combination of positive and negative association between paths, the in-depth analysis of path estimation was done for significance test by analyzing T-values. Based on the T-values, positive attitude, which positively influences compulsive usage, was found to be non-significant. This indicates that the positive attitude towards smartphones plays a non-significant role in influencing the compulsive use of the respondents. The other paths towards social and process usage from positive attitude have a significant relationship, which indicates that the process and social usage of the smartphone user were significantly influenced.

A negative attitude has a significant path towards compulsive and process usage, but a non-significant path towards social usage. It specifies that even negative perception towards smartphones does not prevent people from using them in their daily life, as they become unavoidable in the digital environment. They are in a compulsion to access the smartphones for various purposes, such as 
communication, office work, relaxation, messages/emails, and news, etc. that cannot be evaded. Once digital competencies occupied the lifestyles of people slowly, even negative perceptions of a particular technology could not stop usage. This may be the main reason for the significant path between negative attitude towards compulsive and process usage. If they have negative and unsecured thoughts about some technology, they safely avoid it for developing relationships and social bonding. That was shown in the model through non-significance from negative attitude to social usage. Thus, the socialization through smartphones cannot happen between people having a negative perception.

Anxiety to compulsive and process usage was found to be significant in this research; whereas social usage was found to be non-significant. This shows that in certain cases, the concern of the respondents leads them to use smartphones for different purposes. Even when people worry about the smartphone use, instead they gratify the process needs such as education, banking, security etc. to manage the digital competencies. But when they have anxiety towards smartphone use, they safely avoid it for socialization purpose. Hence the answer to first research question was derived.

The answers to research questions two and three show the influence of age group and gender on attitude and usage. The age of the respondents in this research was not found to be significant towards positive attitude, negative attitude, process usage and social usage. It is significant only towards anxiety and compulsive usage. This indicates that the age is not an influential factor in determining the two types of attitudes and usages mainly used in this research. However, the significance of anxiety and compulsive usage with regards to age group indicates that definite variations exist. The anxiety of loneliness and stronger need for belongingness are a few reasons for people to turn towards smartphones (Pearson, Carmon, Tobola, \& Flowler, 2010). Young people are less likely to react to impulses and used technology as an immediate reward (Metcalf \& Mischel, 1999) and feedback (Howe \& Strauss, 2004). Older adults have different feelings, interests and motivational goals (Diehl, Semegon, and Schwarzer, 2006) compared to younger adults, but avoid the technology if they found it to be distracting. In terms of compulsive usage, younger adults rely on the devices for various office and personal purposes, despite their potential disinterest, whereas older adults safely skip the device if it is negatively perceived (Navabi et al., 2016). Older adults spend less time on social and process usage of smartphones than younger adults. Thus, they experience less social stress (van Deursen et al., 2015). Therefore, the reason for the significant relationship between anxiety and compulsive usage is consistent with the previous researchers.

The multi-group analysis difference between the genders as presented below. A positive attitude relating to compulsive usage is found to have no significant variation by gender. It reflects the same result of the main model. On the other hand, positive attitude towards process usage and social usage are found to be highly significant connections with gender as an influential factor; these connections are seen more among females than males. This shows that the females with a positive attitude are using smartphones more to satisfy their process related gratification and develop their social networks and bonding (van Deursen et al., 
2015). The negative attitude towards process usage was not significant between males and females. In the main model, this difference was negatively influenced and found to be significant. But in gender estimation analysis, this was found to be non-significant. This shows that the particular path is gender neutral.

Negative attitude and anxiety towards compulsive usage and negative attitude towards social usage are highly significant among males. This shows that males are using smartphones for the purpose of social usage and another relevant compulsive behavior more than females (Lee et al., 2014), even if they do not like to do it. They understand the ill effects, complications, and dependency of smartphones, but are still using them more to manage their everyday communication, business, family commitments and other compulsory gratification purposes. Anxiety to process usage is more significant in females, but not significant with social usage for gender. Female's access smartphones more for solving communication problems, developing social bonding, and satisfying their motives (Jenaro et al., 2007; Claisse \& Rowe, 1987). The fear of solving problematic issues of smartphones is more among the female than male which is proved in the model. Females anxiously reject it whereas, males get into it and embrace the technology and solve the problems. However, they are considered as more problematic users than females. The same concept is also supported by Lee et al. (2014) in his study. Thus, anxiety has a role in process usage for females, and the level of usage depends on the anxiety level.

This data also indicates that males are using smartphones more for professional purposes than societal purposes, while females use them to reduce anxiety (Lee et al., 2014). The non-significance of anxiety with social usage shows that gender does not explain variation in this particular item. Overall, smartphones are found to be used commonly between both the genders (Bianchi \& Phillips, 2005), but their approach and usage pattern differs. The same is proved in this research. These previous research results are consistent with the present results.

\section{Conclusion}

The positive attitude has a major role in determining the social and process usage of adults in Chennai. A negative attitude has a key role in compulsive and process usage more than in social usage. This shows that smartphone users in Chennai are very careful in using smartphones for the purpose of developing social relationships, especially when it is perceived negatively. With respect to anxiety, the users avoid smartphones for process usage, but in certain cases, it plays a role in compulsive and social usage, depending on the various external circumstances. Respondents use smartphones for process needs regardless of whether they perceive it as positive or negative. They also develop and maintain relationships using smartphones safely. Overall, this particular research can be a theoretical evidence of how different types of attitude and usage relate with one another among the smartphone users. 


\section{Limitations and Future Directions}

This particular research, which studied the influence of attitude in adult's smartphone usage, also has limitations. This research focused on only one city based on the highest number of mobile users recorded in census. The next few cities based on usage ranking can also be taken further for the study and thus will give comparative results. The respondents' ages in this research range from 20 to 65. To this extensive age group, incorporation of a higher number of samples may produce more accurate results. As the technology competence grows faster, longitudinal study design can also be used to understand the view of people in a different period of time. This research used purposive sampling method. Introduced Simple Random Sampling (SRS) may yield a different result. In this particular research, respondents are heavy smartphone users. The inclusion of light and medium users also, along with all socioeconomic groups, can be added. The educational qualification, profession, and income can also be added as a moderating variable to get different results.

\section{References}

Bianchi, A., \& Phillips, J. G. (2005). Psychological predictors of problem mobile phone use. CyberPsychology \& Behavior, 8(1): 39-51.

Campbell, S. W. (2007). A cross-cultural comparison of perceptions and uses of mobile telephony. New Media \& Society, 9(2), 343-363.

Charness, N., \& Bosman, E. A. (1992). Human factors and age. In F. I. M. Craik \& T. A. Salthouse (Eds.), The handbook of aging and cognition, pp. 495-551. Hillsdale, N.J.: Lawrence Erlbaum.

Chou, C., \& Hsiao, M. (2000). Internet addiction, usage, gratification, and pleasure experience: The Taiwan college students case. Computers \& Education, 35(1), 6580.

Chua, A. Y., Goh, D. H., \& Lee, C. S. (2012). Mobile content contribution and retrieval: An exploratory study using the uses and gratifications paradigm. Information Processing \& Management, 48(1), 13-22.

Claisse, G., \& Rowe, F. (1987). The telephone in question: Questions on communication. Computer Networks and ISDN Systems, 14(2-5), 207-219.

Counterpoint Research. (2017). Smartphone market in India. Market share survey [Data file].

Census India. (2011). Office of the Registrar General \& Census Commissioner, India. Ministry of Home Affairs, Government of India.

David Garson, G. (2016). Partial Least Squares: Regression \& Structural Equation Models. Statistical Publishing Associates.

Devis J. D., Carmen P., Vicente, J. B., \& Thomas, J. M. (2009). Screen media time usage of 12-16 year old Spanish school adolescents: Effects of personal and socioeconomic factors, season and type of day. Journal of Adolescence, 32(2): 213-231.

Diehl, M., Semegon, A. B., \& Schwarzer, R. (2006). Assessing attention control in goal pursuit: A component of dispositional self-regulation. Journal of Personality Assessment, 86(3): 306-317. 
Dvinsky, A., \& Friedman, R. (2015). Chameleon-a group communication framework for smartphones. Journal of Software: Practice and Experience, 45(10), 1429-1455.

Ehrenberg, A., Juckes, S., White, K. M., \& Walsh, S. P. (2008). Personality and selfesteem as predictors of young people's technology use. CyberPsychology \& Behavior, 11(6), 739-741.

Fornell, C., \& Larcker, D. F. (1981). Evaluating structural equation models with unobservable variables and measurement error. Journal of Marketing Research, 18(1): 39-50.

Hair, J., Black. W., Babin, B., Anderson, R., \& Tatham, R. (2010). Multivariate data analysis. Upper Saddle River, N.J.: Pearson Prentice Hall.

Hostut, S. (2010). Uses and gratifications of mobile phone use among students in Turkey. Global Media Journal: Mediterranean Edition, 5(1/2), 10-17.

Howe, N., \& Strauss, W. (2004). Millennials rising: The next great generation. New York: Vintage Books.

IDC-International Data Corporation. (2013). Smartphone use research. [Data file]

IMAI-Internet and Mobile Association of India. (2017). Internet users in India [Data file].

Ihm, J., \& Hsieh, Y. P. (2015). The implications of information and communication technology for the social well-being of older adults. Information, Communication \& Society, 18(10): 1123-1138.

Jenaro, C., Flores, N., Gomez-Vela, M., Gonzalez-Gil, F., \& Caballo, C. (2007). Problematic internet and cell-phone use: Psychological, behavioral, and health correlates. Addiction Research and Theory, 15(3), 309-320.

Kamibeppu, K., \& Sugiura, H. (2005). Impact of the Mobile Phone on Junior High-School Students' Friendships in the Tokyo Metropolitan Area. CyberPsychology and Behavior, 8(2), 121-130.

Krithika, M., \& Vasantha, S. (2013). The mobile phone usage among teens and young adults impact of invading technology. International Journal of Innovative Research in Science, Engineering and Technology, 2(12).

Khatun, M. S., Rana, J., Ali, J. (2017). Consumer's Attitude towards the Use of Smartphone in Bangladesh: A Circumstantial Study on Rangpur Region. European Journal of Business and Management, 9(1).

Kang, S., \& Jung, J. (2014). Mobile communication for human needs: A comparison of smartphone use between the US and Korea. Computers in Human Behavior, 35, 376387.

Lelkes, O. (2013). Happier and less isolated: internet use in old age. Journal of Poverty and Social Justice, 21(1), 33-46.

Lenhart, A., Purcell, K., Smith, A., \& Zickuhr, K. (2010). Social media \& mobile internet use among teens and young adults. Chicago: Pew Internet \& American Life Project.

Lee, Y-K., Chang, C-T., Lin, Y., \& Cheng, Z-H. (2014). The dark side of smartphone usage: Psychological traits, compulsive behavior and technostress. Computers in Human Behavior, 31, 373-383.

Lane, W., \& Manner, C. (2008). The impact of personality traits on smartphone ownership and use. International Journal of Business and Social Science, 2(17).

Matthews, G., Roberts, R. D., \& Zeidner, M. (2004). Seven myths about emotional intelligence. Psychological Inquiry, 15(3), 179-196.

Meerkerk, G. J., Van den Eijnden, R. J. J. M., Vermulst, A. A., \& Garretsen, H. F. L. (2009). The compulsive internet use scale (CIUS): Some psychometric properties. CyberPsychology \& Behavior, 12(1), 1-6.

Metcalf, J., \& Mischel, W. (1999). A hot/cool-system analysis of delay of gratification: Dynamics of willpower. Psychological Review, 106(1), 3-19. 
Muhanna. W. N., Abu-Al-Sha'r, A. M. (2009). University Students' Attitudes towards Cell Phone Learning Environment. International Journal of Interactive Mobile Technologies, 3(4), 35-40.

Navabi, N., Ghaffari, F., Jannat-Alipoor, Z. (2016). Older adults' attitudes and barriers toward the use of mobile phones. Clinical Intervention in Aging, 11, 1371-1378.

Nunnally, J. C. (1978). Psychometric theory. New York: McGraw-Hill Inc.

O'Guinn, T. C., \& Faber, R. J. (1989). Compulsive buying: A phenomenological exploration. Journal of Consumer Research, 16(2), 147-157.

Oulasvirta, A., Rattenbury, T., Ma, L., \& Raita, E. (2012). Habits make smartphone use more pervasive. Personal and Ubiquitous Computing, 16(1), 105-114.

Pearson, J. C., Carmon, A., Tobola, C., \& Fowler, M. (2010). Motives for communication: Why the millennial generation uses electronic devices. Journal of the Communication. Speech \& Theatre Association of North Dakota, 22, 45-56.

Peter, J. P. (1979). Reliability: A Review of Psychometric Basics and Recent Marketing Practices. Journal of Marketing Research, 16(1), 6.

Pew Research Center. (2014). Internet and Technology [Data file].

Phillips, J. G., Butt, S., Blaszczynski, A. (2008). Personality and self-reported use of mobile phones for games. Cyber Psychology and Behavior, 9, 753-758.

Priester, J. R., \& Petty, R. E. (1996). The gradual threshold model of ambivalence: Relating the positive and negative bases of attitudes to subjective ambivalence. Journal of Personality and Social Psychology, 71(3), 431-449.

Rosen, L. D., Carrier, L. M., \& Cheever, N. A. (2013). Facebook and texting made me do it: Media-induced task-switching while studying. Computers in Human Behavior, 29(3), 948-958.

Rotsztein, B. (2003). Problem Internet use and locus of control among college student: Preliminary findings. Paper presented at the 35th Annual Conference of the New England Educational Research Organization, Portsmouth, New Hampshire, April 10, 2003. Retrieved from <http://www.brianrotsztein.com/downloads/.

Song, I., Larose, R., Eastin, M. S., \& Lin, C. A. (2004). Internet Gratifications and Internet Addiction: On the Uses and Abuses of New Media. Cyber Psychology \& Behavior, 7(4).

Statista. (2017). Smartphone users in India. Smartphone user survey [Data file].

van Deursen, A. J. A. M., Bolle, C. L., Hegner, S. M., \& Kommers, P. A. M. (2015). Modeling habitual and addictive smartphone behaviour. The role of smartphone usage types, emotional intelligence, social stress, self-regulation, age and gender. Computers in Human Behavior, 45, 411-420.

Yang, S. C., \& Tung, C. (2007). Comparison of Internet addicts and non-addicts in Taiwanese high school. Computers in Human Behavior, 23(1), 79-96. 